\title{
NEW PHASE IN THE PROCESS OF MAINTENANCE OF THE URBAN AGRICULTURAL AREA OF "L'HORTA DE VALÈNCIA", SPAIN
}

\author{
JOSÉ L. MIRALLES I GARCIA \\ Department of Urban Planning, Polytechnic University of Valencia, Spain
}

\begin{abstract}
On 12 March 2018, the Valencian official bulletin published the Law of "L'Horta de València". In addition, on 20 December 2018, the same bulletin published approval of the Territorial Action Plan for Planning and Revitalizing "L'Horta de València". Both initiatives establish a framework for maintaining the periurban agricultural area of Valencia and allow actions to promote agricultural activities. In 2019, "L'Horta de València" was declared a Globally Important Agricultural Heritage System (GIAHS) by Food Agriculture Organization (FAO) of the United Nations (UN). The municipality of Valencia became the world capital for sustainable food, to promote the Milan Urban Food Policy Pact. Therefore, two years after protection, it is time to review if the new law and planning have produced positive changes in agricultural activities and landscape, and assess which are the current challenges now. Specifically, it's time to know the current situation, problems, limitations and opportunities. This article provides the results of a SWOT analysis about the current situation of agricultural activities and landscape of "L'Horta de València", carried out by semi-structured interviews with a panel of experts involved in elaboration of these documents or who are intervening in management of this space.

Keywords: agricultural land management, agriculture, Globally Important Agricultural Heritage System, peri-urban management, regional planning, sustainable farming, urban agriculture, Valencia, vegetable farming.
\end{abstract}

\section{INTRODUCTION}

Valencia's "Huerta" (vegetable farm) is an extraordinary peri-urban agricultural space that is the object of many studies. This long-studied space is today a protected space, managed by a special system regulated by law. All studies have in common the positive evaluation of this singular landscape.

According to Antolín Tomás et al. [1], a long time ago in about 1990, the lands of high agrological capacity in the Valencian community represented only $3.9 \%$ of the surface of the Valencian territory, in two main spaces: the fertile plain of the Turia river in Valencia, or Valencia's "Huerta"; and the fertile plain of the lower valley of the Segura river south of Alacant. As a referent, according to Boira [2], in 2006, the urbanized areas were $5.41 \%$ of the Valencian territory. That is, the surface of high-capacity agricultural lands is less than the surface of artificial lands. Fig. 1 shows the location of periurban agricultural land protected around Valencia today.

In the period of transition to democracy, about 1978, was born a social movement to protect and maintain this singular space [3]. Progressively, a social majority was generated in favor of this idea; however, at the same time, the Valencian community underwent an accelerated process of urban expansion that transformed many rural areas, including an important part of the peri-urban agricultural land of "L'Horta".

Urban expansion on the Mediterranean coast of Spain began in the 1960s [4]. Public administration promoted a big touristic resort in L'Albufera Lake, such as the project of La Manga del Mar Menor, in Murcia, Spain [5]-[8]. This project generated a very strong social 
movement against the destruction of spaces with environmental value, like L'Albufera Lake, the periurban agricultural area of "L'Horta" and the old Turia riverbed [9].

Many studies analyzed different characteristics of this singular and complex space. The situation and evolution of "L'Horta de València" is a subject for continuous analysis. It is an

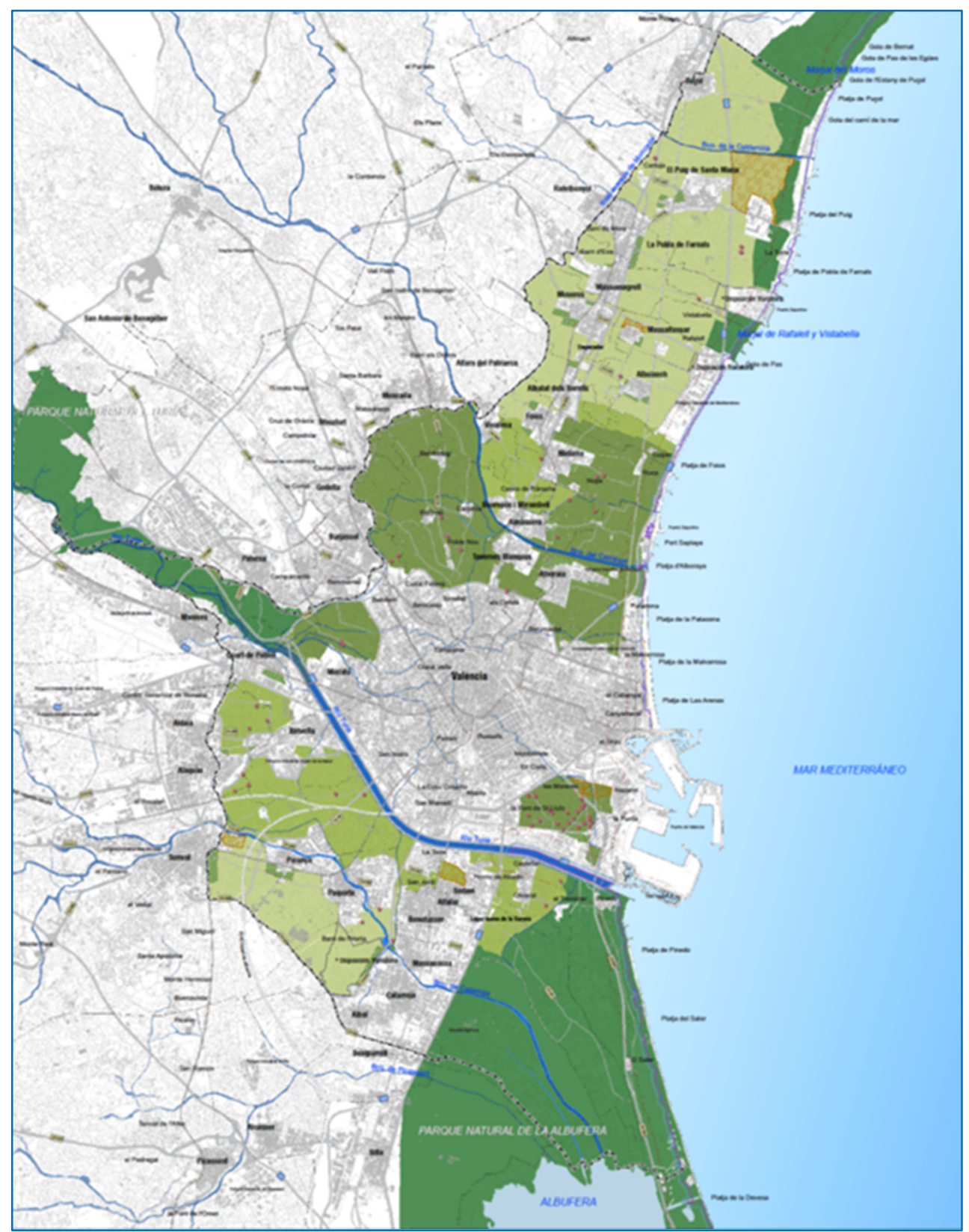

Figure 1: Geographical area of the peri-urban agricultural space of Valencia's "Horta" and zoning for different kinds of agricultural areas, according to their quality [19]. 
identity element of Valencian society; many authors focus their attention on it. Romero and Francés [10] coordinated their work with an update on global diagnosis. Temes and Moya [11], [12] studied the evolution and dynamics of agricultural landscape changes. TemesCordovez et al. [13] researched the evolution of different periurban agricultural areas in Spain. Miralles i García [14] studied the environmental management problem in periurban areas. Marqués Pérez et al. [15] focused their research on evaluating the agricultural system. Romero and Melo [16]; and more recently, Melo [17] have studied the current situation and dynamics of this landscape.

In addition, the Valencia Council organized the "2017 Milan Urban Food Policy Pact Annual Gathering and Mayor's Summit". One of the results was the document "Estrategia Agroalimentaria. València 2025" (Agro-alimentary strategy for Valencia 2025) [18].

As a result of the social movement and studies, in 2006 the "Pla d'Acció Territorial d'Ordenació i Dinamització de L'Horta de València", (Territorial action plan to regulate and revitalize L'Horta de Valencia, in Catalan) finally began to be elaborated upon by the Regional Government that was approved in December 2018 (12 years later). In addition, according to results of analyses of studies begun about the situation of agricultural land of L'Horta, its problems and possible actions to maintain this anthropic landscape; in 2015, the new Regional Government began the elaboration of a law to manage this singular space. Finally, on 6 March 2018, the L'Horta Law [20], or Llei de L'Horta de València, in Catalan, or Ley de la Huerta de Valencia, in Spanish, was passed and published on 12 March 2018.

These two tools fundamentally change the situation, to protect and manage the agricultural land of "L'Horta de València". Note that this land is a natural resource, transformed and managed by farmers. It is only possible to maintain this space or landscape if the agricultural activity is maintained. Obviously, to maintain agricultural activity in this big area, we need a public policy with public-private collaboration, to promote the many activities and initiatives that farmers cannot do in an individual way.

These two tools, the Territorial Plan and Law, have different objectives. The Plan is a passive way to establish planning uses in the territory. The Law establishes a framework to do initiatives in favor of agricultural or complementary activities. That is, it is a tool for creating an active way to maintain agriculture activities. Both are complementary.

The Plan establishes a framework of land use in three general areas [19], within an extended area with a surface 63,400 ha. This surface includes, totally or partially, the territory of 44 municipalities. This area includes the agricultural land of "L'Horta de València" plus a buffer zone around it. Inside this area, there are: the strict area of "L'Horta de València" including urban areas and irrigation infrastructures, with a total surface of 22,900 ha and 40 municipalities. Inside this strict area there are about 11,393 ha of protected agricultural land (named "protected not developable land" in Valencia, according to Urban Law). This is the agricultural land at the initial time of Plan preparation. The Plan includes written and graphic regulations that are mandatory (for all public and private agents, except Central Administration, because regional rules/plans cannot bind the highest level of administration in Spain). The new way of planning and managing protected agricultural land was studied in detail by the collective work directed by Marzal Raga [21].

The Law establishes a complex system to manage this singular territory, based on three axes in addition to "Territorial Action Plan to Regulate and Revitalize the Huerta of Valencia" axes [22]: the elements that make up the "Huerta", the L'Horta Council and the Agrarian Development Plan.

The Law establishes the main management objectives and a check of possible tools. The "L'Horta Council" is an office with a budget that depends on regional administration and participation of the main private agents interested in agricultural activities and environmental 
values of the Huerta. In fact, the "L'Horta Council" is the managing entity meant to promote initiatives in order to revitalize agricultural activities or others, according to the framework established in the law. Maybe one of its main functions is to elaborate on the Agrarian Development Plan as a tool to improve agricultural activity and its profitability [23].

All these new tools establish a very innovative new framework to manage this singular space and natural resource. For this reason, it is necessary to rethink the new situation, analyzing the possibilities that the new situation allows, and checking whether the objectives are being met.

Finally, in 2019, the United Nations (UN) Food and Agriculture Organization (FAO) registered "L'Horta de València" as a Globally Important Agriculture Heritage System. The report with the proposal is the last international award regarding "L'Horta de València" and its irrigation system [24]. Note that this irrigation system is historical, with a specific historical court to solve problems about irrigation between the farmers inscribed in 2009, as an Intangible Cultural Heritage site by UNESCO [25].

\section{OBJECTIVES AND METHODS}

As seen in Section 1, the plan and the law about "L'Horta de València" are two tools that have generated a new situation through possibilities and management of the periurban agriculture of Valencia.

In addition, it is necessary to remember some international trends about management of territory; particularly, it is interesting remember two trends that focus on possible new points of view. First, the concept of "smart territory" as an evolution from the "smart city" concept [26]. In fact, it is possible to have an agricultural production system based on demand in real time, by a semi-automatized way. The use of applications via the internet can change the way production occurs, independently of the kind of production (certified organic, not certified organic or conventional). Secondly, the planning of metropolitan areas implies specific criteria for maintaining green infrastructures inside them, and to avoid territory fragmentation [27] as a strategy to transform the territories in sustainable areas.

The aim of this research is to identify the characteristics of the new situation of the space called "L'Horta de València" after the introduction of two new tools, the plan and the law, which are being applied, and also to identify any new challenges.

To achieve this goal, we did a SWOT analysis (strengths, weaknesses, opportunities, threats) as a synthesis of a semi-structured survey, carried out with a group of five specialists. These specialists are people, not politicians, but with a very significant role in the processes to elaborate and design the plan and/or the law to protect and promote "L'Horta" of Valencia. The interviewees work in different sectors interested in maintaining and promoting agricultural activity of this peri-urban space: university specialists, representative agrarian union people that usually do conventional agriculture, farmers that produce (or want to produce organic agriculture but without the interest to certificate it, organic farmer entrepreneurs, and NGO environmental associations. All these people are specialist technicians or professionals in the subject under study. The interviews have been done individually, in part before confinement, because of the Coronavirus situation; and in part after confinement. Confinement has affected the demand and production of agricultural products.

\section{RESULTS}

Tables 1-4 show a synthesis of the SWOT analysis. The analytical elements were grouped by topic. The elements identified by two $(*)$ or more $(* *)$ interviewees have been marked. 
As you can see, in the weaknesses, Table 1 presents the largest list of items that includes eight topics. The first weakness detected focuses on governance problems. There is a general awareness that the action of the regional public administration is necessary to implement actions that farmers cannot carry out by themselves. In fact, a great effort has been made by the regional public administration to prepare and approve the Plan and the "L'Horta" Law; but all those interviewees surveyed consider that, at this time, there is a certain lack of initiative to implement the planned actions. Note that this agriculture is by smallholding, so it is very difficult to do coordinated actions based on private initiatives, especially for strategic actions.

Table 1: Synthesis of weaknesses.

\begin{tabular}{|c|c|}
\hline & Weaknesses \\
\hline \multirow{4}{*}{ Governance } & $\begin{array}{l}\text { Lack of initiative from the public administration (the Horta } \\
\text { Council).** }\end{array}$ \\
\hline & $\begin{array}{l}\text { Horta Law is a social pact to protect and promote L'Horta, but there } \\
\text { are pending problems about several urban expansions.* }\end{array}$ \\
\hline & $\begin{array}{l}\text { Horta Law has not avoided infrastructures such as motorways or } \\
\text { railways promoted by the Central Administration, within the } \\
\text { protected area. }\end{array}$ \\
\hline & $\begin{array}{l}\text { Lack of coordination between different social and public agents to } \\
\text { achieve common objectives (e.g. the local administration). Lack of } \\
\text { collaboration between the agrarian union, farmers and politicians.* }\end{array}$ \\
\hline \multirow{3}{*}{$\begin{array}{l}\text { Behavior of big } \\
\text { powers }\end{array}$} & $\begin{array}{l}\text { Lack of compromise of organizations (administration, universities, } \\
\text { great trades...) with capacity and power to promote a new urban } \\
\text { concept that includes protection of areas which produce ecosystem } \\
\text { services. }\end{array}$ \\
\hline & $\begin{array}{l}\text { Sometimes, dogmatic position of some political manager that can } \\
\text { produce a loss of allies (e.g. housewife). }\end{array}$ \\
\hline & $\begin{array}{l}\text { Risk that Horta's Council will disappear when future political } \\
\text { changes occur. }\end{array}$ \\
\hline \multirow{3}{*}{$\begin{array}{l}\text { Behavior of } \\
\text { social agents }\end{array}$} & $\begin{array}{l}\text { Lack of consensus among all social agents in favor of promoting } \\
\text { agricultural activities on the way to act. }\end{array}$ \\
\hline & $\begin{array}{l}\text { Agrarian union representation in Horta's Council not proportional to } \\
\text { the importance of each union, and little weight of global } \\
\text { representation, compared to the representation of the administration. }\end{array}$ \\
\hline & $\begin{array}{l}\text { Some disappointment among the conventional farming community. } \\
\text { Expectations have been created that have not been met. }\end{array}$ \\
\hline \multirow{5}{*}{$\begin{array}{l}\text { Agricultural } \\
\text { profitability }\end{array}$} & Costs produced when farmers manage dispersed small fields. \\
\hline & Weak ability to negotiate sales prices, due to smallholdings. \\
\hline & Differences of interest and behavior between farmer and trader. \\
\hline & Greater control of commercialization and the value chain. \\
\hline & Territorial fragmentation and creation of residual fields. \\
\hline
\end{tabular}


Table 1: Continued.

\begin{tabular}{|c|c|}
\hline & Weaknesses \\
\hline \multirow{9}{*}{ Agrarian policy } & $\begin{array}{l}\text { Agrarian Development Plan too focused on organic agriculture when } \\
\text { about } 90 \% \text { of production is conventional agriculture. }\end{array}$ \\
\hline & Agrarian Development Plan is not being executed. \\
\hline & $\begin{array}{l}\text { Horta's Council budget is too oriented upon surveillance against crop } \\
\text { theft, but little on infrastructure or other productive investments. }\end{array}$ \\
\hline & $\begin{array}{l}\text { Dichotomy between organic (today with little production but } \\
\text { growing) and conventional agriculture (today a majority, but with a } \\
\text { difficult future). }\end{array}$ \\
\hline & $\begin{array}{l}\text { Dichotomy between ecologic dogmatism and pragmatism about } \\
\text { reality. }\end{array}$ \\
\hline & $\begin{array}{l}\text { Obsolete conventional agriculture because negative environmental } \\
\text { impacts. }\end{array}$ \\
\hline & $\begin{array}{l}\text { There are no clear rules about use of chemical products in } \\
\text { agriculture. Lack of control in it use. }\end{array}$ \\
\hline & Abandoned fields are a problem (rats, rabbits, bad grass/weeds...). \\
\hline & Generational farmer chain broken and aging active farmers.* \\
\hline \multirow{5}{*}{ Knowledge } & $\begin{array}{l}\text { It is necessary to have a detailed study to know better: production, } \\
\text { stakeholders, land grouping, field structure... }\end{array}$ \\
\hline & $\begin{array}{l}\text { There is an observatory, but prices, distribution and the value chain } \\
\text { are not well known. }\end{array}$ \\
\hline & $\begin{array}{l}\text { Training need (crop management, sales management by internet...). } \\
\text { There is one farmer's school, but it is inefficient, according to } \\
\text { current needs. }\end{array}$ \\
\hline & $\begin{array}{l}\text { Lack of cultural synergy between the university and traditional } \\
\text { knowledge about agriculture. }\end{array}$ \\
\hline & $\begin{array}{l}\text { In general, society does not understand how huerta agriculture } \\
\text { works.* }\end{array}$ \\
\hline Communication & Biased information on public TV. Need an open discussion. \\
\hline \multirow{2}{*}{ Environment } & Land pollution by the use of agrochemicals. \\
\hline & Low quality of irrigation water. \\
\hline
\end{tabular}

On the other hand, Horta's Council, with membership of all stakeholders, has a public budget; and in consequence, public administration has the majority of members. So stakeholders with direct interests have not a majority. In addition, these stakeholders have different points of view. It is difficult to manage this situation. To solve this problem, it is necessary to have a proactive attitude of public administration and politicians.

The second topic is about behavior of big powers, public and private. Really, public administration includes several different organizations with different strategies; and policy is not always coordinated between them. However, if strategic actions to promote agricultural 
products depends on public administration, there is the risk of changes when politicians change, especially in long-term actions. On the other hand, some private businesses have the ability to change framework, especially large commercial companies that can do policies to promote agricultural local production or fix prices and conditions.

In addition, social agents not always have the same interest. In consequence, it can be difficult to have a consensus between all of them, to effect strategic actions.

Besides, agricultural production has profitability problems. This question must be qualified according to the effects of the COVID-19 pandemic. In fact, the pandemic has produced an increased demand from Spain and the EU, especially for organic products. Part of the interviews was done before the pandemic and others after confinement; so there could be different perceptions, before and after confinement.

It was to be expected that agrarian policy is an important topic. "L'Horta" produces three kinds of agricultural products: conventional, not certified organic and certified organic. Now, the more important production is conventional (around 90\%); but it is the form of production with more profitability problems. Organic agriculture is today a minority, but it is growing. The pandemic is producing an increase in demand, due to changes in consumer behavior; however, the certified organic products is complicated for the smallholder. In consequence, some farmers work with uncertified organic agriculture. Moreover, the side-by-side coexistence between organic and non-organic agriculture is difficult. Maybe this is one of the main important problems to solve.

On the other hand, the possibilities of "vertical farms" to make all kinds of agricultural products, organic and not-organic, could be, in the near future, the most important challenge. This question introduces the next topic, that is, the need for knowledge about management of production with new technologies, in the global market. The Internet and applications for "smart territory" are going to change how we understand agricultural food production, especially in a smallholder situation. Traditional farmers are formed in other ways to manage both land and market. It is necessary to find a way to combine traditional knowledge with new technologies. Communications with society and about the environment close the list of weaknesses.

In Table 2, you see the synthesis of the main threats as four topics: agricultural profitability, technical innovation, new transportation infrastructures, and urban development and agrarian policy. Among them, we underline the low demand from foreign markets (before the pandemic, particularly in the case of EU markets) due in part to Brexit, a prepandemic general agrarian crisis and agrarian policy.

The agricultural surface on "L'Horta" is big, and the local market of metropolitan area of Valencia is not large enough to consume all production. For this reason, an important part of production normally goes out mainly to EU markets; however, due to the pandemic, the EU increased its demand for agricultural products from EU countries, for security reasons.

The demand for organic product is increasing, so that is a problem for those using conventional agriculture, which is at the time the majority of production. This problem is a threat, but also an opportunity, that requires an effort to reconvert the profile of farmers, from being a traditional farmer to becoming a professional specialized in new technologies, and control and management systems, who takes advantage of popular knowledge about the agriculture of "L'Horta".

As already mentioned, maybe the main threat is the probable evolution of agriculture to a "vertical farm" system. Despite its important energy consumption, it can be a very competitive system for agricultural production, even of organic food. In this case, it will be 
Table 2: Synthesis of threats.

\begin{tabular}{|c|c|}
\hline & Threats \\
\hline \multirow{5}{*}{$\begin{array}{l}\text { Agricultural } \\
\text { profitability }\end{array}$} & $\begin{array}{l}\text { Unfair competition from third world countries with lower } \\
\text { phytosanitary requirements. }\end{array}$ \\
\hline & $\begin{array}{l}\text { Agrarian crisis, with prices below the cost of production (before } \\
\text { Coronavirus). }\end{array}$ \\
\hline & Lack of a foreign market. \\
\hline & $\begin{array}{l}\text { Certificate of organic agriculture has rigorous controls that penalize } \\
\text { farmers, especially when there is a mix of conventional and organic } \\
\text { agriculture. }\end{array}$ \\
\hline & The great stores can control prices and impose conditions. \\
\hline \multirow[t]{2}{*}{$\begin{array}{l}\text { Technical } \\
\text { innovation }\end{array}$} & $\begin{array}{l}\text { Probably "vertical farms" will be the immediate future of } \\
\text { agricultural production, via hydroponic and aeroponic crops. Today } \\
\text { it is more expensive, but the cost of production will probably go } \\
\text { down. Can make organic agriculture with absolute control of all the } \\
\text { parameters, in buildings or warehouses. }\end{array}$ \\
\hline & Emergence of a new kind of farmer: "vertical urban farmer" \\
\hline \multirow{4}{*}{$\begin{array}{l}\text { New transport } \\
\text { infrastructure } \\
\text { and urban } \\
\text { development }\end{array}$} & $\begin{array}{l}\text { Central Administration is planning the expansion of transportation } \\
\text { infrastructures that already exist (motorways) or the construction of } \\
\text { new infrastructures (high speed railway). }\end{array}$ \\
\hline & $\begin{array}{l}\text { New transport infrastructures produce an irreversible } \\
\text { transformation of agricultural lands, fragmentation and may render } \\
\text { residual fields unusable. }\end{array}$ \\
\hline & $\begin{array}{l}\text { Use of protected agricultural land as a reserve to implement new } \\
\text { infrastructures or urban development. }\end{array}$ \\
\hline & Urban pressure to build in protected areas. \\
\hline \multirow{3}{*}{ Agrarian policy } & $\begin{array}{l}\text { Traditional seed chain is breaking (dependence on the foreign } \\
\text { market for seeds). }\end{array}$ \\
\hline & $\begin{array}{l}\text { Lack of interest of the new generations to work in agriculture is } \\
\text { aggravated by a lack of profitability. }\end{array}$ \\
\hline & Lack of results gives risk of going backwards in the process. \\
\hline
\end{tabular}

necessary to find other added values, to make the agriculture of these of "L'Horta" lands competitive. Agrarian policy is important in addressing this question.

Finally, new transportation infrastructures and urban development remain a major threat. They destroy agricultural land and fragment it irreversibly. The risk of land speculation is always latent. The legal framework of land ownership in Spain facilitates speculation when the right economic conditions exist. It is possible to speculate on the land if its legal protection is changed. 
Table 3 shows the synthesis of strengths. Despite all its problems, still the agricultural lands of "L'Horta" have many strengths. Having a plan and a law approved about agricultural lands of "L'Horta" is already a strength. There are many social agents to maintain, protect and promote the agricultural land of "L'Horta", with a very high valuation as a heritage site for L'Horta. There is international recognition of positive values of "L'Horta", especially about water management and irrigation. This traditionally agricultural land is a sustainable system because it has been operating without interruption for more than 1,000 years. Although not many, there are young entrepreneurs willing to promote new forms of agriculture who are more competitive and have adapted to new challenges.

Table 3: Synthesis of strengths.

\begin{tabular}{|c|c|}
\hline \multicolumn{2}{|r|}{ Strengths } \\
\hline Governance & $\begin{array}{l}\text { Horta Law is key to stopping the urbanization/destruction of good } \\
\text { agricultural soil. }\end{array}$ \\
\hline \multirow{6}{*}{$\begin{array}{l}\text { Behavior of } \\
\text { social agents }\end{array}$} & $\begin{array}{l}\text { There is a strong social movement, very diverse and with a lot of } \\
\text { initiative, in favor of Horta agricultural land. It is a bottom-up } \\
\text { entrepreneurship system.* }\end{array}$ \\
\hline & An important part of the local administration shares this movement. \\
\hline & $\begin{array}{l}\text { Consumer attitude change: there is a major demand for local and } \\
\text { organic products. }\end{array}$ \\
\hline & There are some groups of enterprising young farmers. \\
\hline & Very positive social assessment of the agricultural heritage of L'Horta.* \\
\hline & $\begin{array}{l}\text { There is an effective and traditional water management community, } \\
\text { with a Water Court. It is a collaborative and self-organizing tradition. }\end{array}$ \\
\hline \multirow{4}{*}{ Environment } & $\begin{array}{l}\text { The Huerta is an agriculturally sustainable system that has existed there } \\
\text { for more than } 1000 \text { years. }\end{array}$ \\
\hline & $\begin{array}{l}\text { The traditional irrigation system helps against climate change, the hot } \\
\text { island phenomenon and hot waves. }\end{array}$ \\
\hline & Huerta-swamp symbiosis increases raining. \\
\hline & The Huerta system increases biodiversity. \\
\hline Cultural & "L'Horta" is an identity referent and a cultural landscape. \\
\hline $\begin{array}{l}\text { Agricultural } \\
\text { profitability }\end{array}$ & $\begin{array}{l}\text { Small-scale farming has drawbacks but also advantages: diversification } \\
\text { of crops, diversification of value chains, versatility, diversification of } \\
\text { commercial models. }\end{array}$ \\
\hline
\end{tabular}

From an environmental point of view, the peri-urban agricultural land is an important green infrastructure adjacent to the metropolitan area of Valencia. It is also an element of identity to Valencian society. Small-scale farming has drawbacks, but also advantages.

Finally, Table 4 shows a synthesis of opportunities. In fact, there are many opportunities from the point of view of governance, agricultural profitability, technical innovation and behavioral changes by social agents in favor of this space. 
Table 4: Synthesis of opportunities.

\begin{tabular}{|c|c|}
\hline & Opportunities \\
\hline \multirow{10}{*}{ Governance } & $\begin{array}{l}\text { SIPAM-FAO registration: It is an international award that can help to } \\
\text { create a mark, promote rural and cultural tourism, create professional } \\
\text { farmers. }\end{array}$ \\
\hline & $\begin{array}{l}\text { Definition and identification of professional farmers (organic and } \\
\text { conventional agriculture).** }\end{array}$ \\
\hline & $\begin{array}{l}\text { Horta's Council can take initiatives and planning actions because it has } \\
\text { the budget and the ability. }\end{array}$ \\
\hline & Horta's Council is an entity open to all sensibilities. \\
\hline & Promoting food sovereignty of metropolitan Valencia.* \\
\hline & Make organic farming and conventional farming compatible. \\
\hline & Mix inspection teams: technical experts + farmers. \\
\hline & Make groups for collaborative economy in agriculture. \\
\hline & Need for supra-individual organization. \\
\hline & $\begin{array}{l}\text { EU Recovery Plan promoted because of COVID is an opportunity to } \\
\text { transform peri-urban agriculture. }\end{array}$ \\
\hline \multirow{7}{*}{$\begin{array}{l}\text { Agricultural } \\
\text { profitability }\end{array}$} & $\begin{array}{l}\text { Promoting more competitive farmers/rural companies by increasing } \\
\text { farm size, making origin-identified products, promoting proximity } \\
\text { markets*, land grouping...* }\end{array}$ \\
\hline & Promoting land stewardship to maintain agriculture and the landscape.* \\
\hline & $\begin{array}{l}\text { Carrying out a study for a long-term horizon set of years (e.g. } 20 \\
\text { years), in order to analyze how to defend the heritage of "L'Horta" } \\
\text { (envisioning). }\end{array}$ \\
\hline & $\begin{array}{l}\text { Coronavirus brought increasing demand of local products and organic } \\
\text { agriculture in Valencia, Spain and Europe.* }\end{array}$ \\
\hline & Create a direct distribution system between farmers and consumers. \\
\hline & $\begin{array}{l}\text { Last economic crisis (before Coronavirus) generated a limited return of } \\
\text { workers to agriculture activity. }\end{array}$ \\
\hline & $\begin{array}{l}\text { Possibilities of agricultural wholesale market (MERCAVALENCIA): } \\
\text { management of "tira de comptar" for direct sales, sales of processed } \\
\text { products, online sales and house distribution, offering of certified } \\
\text { organic products and traditional products (non-certified organic } \\
\text { products). }\end{array}$ \\
\hline $\begin{array}{l}\text { Technical } \\
\text { innovation }\end{array}$ & $\begin{array}{l}\text { Take advantage of technological changes, e.g. by APPs to sell fresh } \\
\text { food. }\end{array}$ \\
\hline $\begin{array}{l}\text { Behavior of } \\
\text { social agents }\end{array}$ & ality in favor of local products. \\
\hline
\end{tabular}




\section{CONCLUSIONS}

Despite the great effort made to elaborate and approve the plan (2019) and law (2018) of "L'Horta" with a very high technical quality, in reality these achievements are only tools to do actions. To date, there are still no visible results. All possibilities are open. There are still weaknesses and threats, but also significant strengths and opportunities. It is urgent that the Horta Council take the initiative to develop and implement concrete actions, with visible results that generate hope among the stakeholders. Many of these actions are included in the Law of L'Horta itself. It is necessary to create collaborative work between stakeholders, to gain success against the challenges.

\section{REFERENCES}

[1] Antolín Tomás, C. et al., El suelo como recurso natural en la Comunidad Valenciana (The Soil as a Natural Resource in Valencia's Community), Generalitat Valenciana, Conselleria d'Obres Públiques, Urbanisme i Transports: Valencia, 1998.

[2] Boira, J.V., Urbanismo expansivo: de la utopía a la realidad (Expansive urbanism: from utopia to reality). Proceedings of XXII Congreso de Geógrafos Españoles, pp. 79-90, 2011.

[3] Miralles i García, J.L., La iniciativa legislativa popular per L’Horta de València (Historical popular legislative initiatives for L'Horta of Valencia). València, 18082015: la historia continua, Balandra Edicions: Valencia, pp. 217-231, 2016.

[4] Miralles i Garcia, J.L., Real estate crisis and sustainability in Spain. WIT Transactions on Ecology and Environment, vol. 150, WIT Press: Southampton and Boston, pp. 123133, 2011.

[5] Miralles i Garcia, J.L. \& Martínez Llorens, F., Tourist development and planning on the Valencian Mediterranean coast: The case of La Devesa del Saler. WIT Transactions on Ecology and the Environment, vol. 217, WIT Press: Southampton and Boston, pp. 495-507, 2018.

[6] García-Ayllón, S., La Manga case study: Consequences from short-term urban planning in a tourism mass destination on the Spanish Mediterranean coast. Cities, 43, pp. 141-151, 2015.

[7] Miralles, J.L. \& García-Ayllón, S., The economic sustainability in urban planning. Case: La Manga. WIT Transactions on Ecology and the Environment, vol. 173, WIT Press: Southampton and Boston, pp. 279-290, 2013.

[8] García-Ayllón, S. \& Miralles, J.L., The environmental impacts of land transformation in the coastal perimeter of the Mar Menor lagoon (Spain). International Journal of Design Nature and Ecodynamics, 9(2), pp. 109-128, 2014.

[9] Mateu, A. \& Domínguez, M., Cuando El Saler volvió al pueblo (When El Saler was returned to the people). Mètode, 70, 2011. http://metode.cat/es/Revistas/Dossiers/LaAlbufera-de-Valencia/Quan-el-Saler-torna-al-poble. Accessed on: 29 May 2020.

[10] Romero, J. \& Francés, M., La Huerta de Valencia. Un paisaje cultural con futuro incierto (Valencian Vegetable Farming. A Cultural Landscape with an Uncertain Future), Universitat de València: Valencia, 2012.

[11] Temes, R. \& Moya, A., Dynamics of change in the peri-urban landscape of Huerta de Valencia: The case of La Punta (Valencia). WIT Transactions on Ecology and the Environment, vol. 192, WIT Press: Southampton and Boston, pp. 123-131, 2015.

[12] Temes, R. \& Moya, A., Typology of the transformations occurred in the peri-urban space of "Huerta de Valencia": Evidence from north arch of Valencia, Spain. International Journal of Sustainable Development and Planning, 11(6), pp. 996-1003, 2016. 
[13] Temes-Cordovez, et al., Las huertas periurbanas del Mediterráneo (Murcia-AlicanteValencia y Zaragoza). Primeros resultados de investigación para el caso de Valencia (Mediterranean peri-urban vegetable farms (Murcia, Alicante, Valencia and Zaragoza). First results from investigating the case of Valencia). Proceedings of III International Congress ISUF-H, pp. 41-55, 2019.

[14] Miralles i García, J.L., Environmental management of peri-urban natural resources: L'Horta de Valencia case study. WIT Transactions on Ecology and the Environment, vol. 192, WIT Press: Southampton and Boston, pp. 99-110, 2015.

[15] Marqués Pérez, I., Segura, B. \& Maroto, C., Evaluating the functionality of agricultural systems: Social preferences for multifunctional peri-urban agriculture. The "Huerta de Valencia" as case study. Spanish Journal of Agricultural Research, 12(4), pp. 889901, 2014.

[16] Romero, J. \& Melo, C., Spanish Mediterranean huertas: Theory and reality in the planning and management of peri-urban agriculture and cultural landscapes. WIT Transactions on Ecology and the Environment, vol. 193, WIT Press: Southampton and Boston, pp. 585-595, 2015.

[17] Melo, C., "L'Horta de València": Past and present dynamics in landscape change and planning. International Journal of Sustainable Development and Planning, 15(1), pp. 28-44, 2020.

[18] Estrategia Agroalimentaria. València 2025. Ajuntament de Valencia: València, 2018. https://hortaipoblesvalencia.org. Accessed on: 29 May 2020.

[19] Pla d'Acció Territorial d'Ordenació i Dinamització de l'Horta de València; Conselleria d'Habitatge, Obres Públiques i Vertebració del Territori, Generalitat Valenciana. www.habitatge.gva.es/ca/web/planificacion-territorial-e-infraestructuraverde/huerta-de-valencia. Accessed on: 16 May 2020.

[20] Ley 5/2018, 6 Mar., de la Generalitat de la Huerta de València. Generalitat Valenciana: Valencia. www.dogv.gva.es/datos/2018/03/12/pdf/2018_2459.pdf. Accessed on: 29 May 2020.

[21] Marzal Raga, R. (ed.), El suelo rural periurbano: Estudio del caso: L'horta de València (Rural Peri-Urban Soil: Case Study of L'Horta of Valencia), Editorial Aranzadi Thomson Reuters: Spain, 2019.

[22] Miralles i Garcia, J.L., New policies for the management of peri-urban agricultural spaces: The case of "L'Horta de València" (Spain). International Journal of Design and Nature and Ecodynamics, 13(4), pp. 361-372, 2018.

[23] Pla de Desenvolupament Agrari de L'Horta de València, Generalitat Valenciana, Conselleria d'Agricultura, Desenvolupament Rural, Emergència Climàtica i Transició Ecològica. www.agroambient.gva.es/va/web/agricultura/novedades/-/asset_publisher/ cDoEgHxQ2gTH/content/plan-de-desarrollo-agrario-de-la-huerta-de-valencia.

Accessed on: 29 Jun. 2020.

[24] Food and Agriculture Organization of the United Nations, Historial Irrigation System at L'Horta de València, Globally Important Agricultural Heritage Systems. UNFAO: Geneva. www.fao.org/3/ca8304en/ca8304en.pdf. Accessed on: 29 May 2020.

[25] Tribunal de las Aguas. www.tribunaldelasaguas.org/en/. Accessed on: 29 May 2020.

[26] Garcia-Ayllon, S. \& Miralles, J.L., New strategies to improve governance in territorial management: Evolving from "smart cities" to "smart territories". Procedia Engineering, 118, pp. 3-11, 2015.

[27] Jalkanen, J., Toivonen, T. \& Moilanen, A., Identification of ecological networks for land-use planning with spatial conservation prioritization. Landscape Ecology, 35, pp. 353-371, 2020. 